\title{
Prayer Determination toward Employees Performance
}

\author{
Chablullah Wibisono ${ }^{1}$ \\ ${ }^{1}$ Batam University Lecturer, Indonesia \\ Correspondence: Priyono, Graduate Program Master of Management, University of Bina Darma Palembang, Indonesia.
}

Received: February 20, 2017

Accepted: April 11, $2017 \quad$ Available online: April 18, 2017

doi:10.11114/ijsss.v5i5.2360

URL: https://doi.org/10.11114/ijsss.v5i5.2360

\begin{abstract}
Prayer is a consequence for person who belief to God as their duty by performing in five times a day. Those are dawn Dzuhur, Ashar, Maghrib and sobs Prayer is the pillars of Muslim, "whoever does the direction, they has heighten their religion, whoever leave means has moved down theirs. Prayer will bring positive impact to performance of human if there is good process that followed and done constantly.

According to Rais (1998:60) a good way in Prayer could give good charity to Muslims itself while if not, so the charity for them must be not well. Although more Muslim people come to mosque, it doesn't show that in society they do not do disavowal. Like have been stated by Rais (1998: 60) the answer is 'because the soul of Prayer didn't life in its person". They might do Prayer practically and routine but don't draw it in their daily life.

Allah SWT asks Muslims to give to the poor and sick of human living in this world. It is called as zakat. like in this quote "....give zakat and give loan to Allah a goodly loan, and whatever good you send before you yourself" (Q.S.Al Muzammil: 20). This letter is not without meaning, the writer thought that there is a significant relationship in causality between prayer and zakat. Based on this theory someone who do Prayer frequently will give maximum in doing Zakat. Here, the writer can say that this Muslim categorize as success person economically. Isn't the fac $t$ ? . In empirical way the writer can see that the social community whose actively do Prayer cannot be portrayed the same, it means that not all of them represent the positive performance. Hence, the writer interested to this topic about does prayer bring positive influence toward employee performance or conversely?

The results of structural equation modelling analysis show that Prayer is directly influence on work performance with negative value. It can be indicated by a coefficient -1.35 with the probability for 0.00 . it can be inferred that there is negative influence when the motivation to do Prayer are high the performance will be low. This effect isn't relevant with the theory which stated the number of praying, Prayer and Fasting can be as much higher motivation toward the quality of performance. Those potentiality is divine asset that should be managed well in establishing the charity (Tasmara, 1995: 77). God. Give his blessing to all human with those potentialities in order to make consciousness about how pray can bring big influence to the performance. Hopefully, this article are functioned as well as finding the heighten of employee performance with Prayer suitable with Muslim studies as whole.
\end{abstract}

Keywords: prayer determination, toward, employee's performance

\section{Introduction}

Is Prayer truly able to improve the performance of someone in their activity? From company side, is the employee discipline on doing Prayer will influence the company performance? In what correlation those can be explained? On what perspective are those indications happen? Here, all of the question above will be discussed clearly.

In fact, the answer to those questions has been answered on the previous sections in the discussion of Prayer, praying and fasting with its specific derivation toward the influence of employee performance. In this paper, the writer focuses on prayer as the positive influence for the employee performance and finally it will give a big significant on company performance. Indeed, the discussion of prayer is coming with the basic understanding about the right essence of Prayer belief and willing to God. Thus, prayer is not only stand alone, it must be followed by another worship like the nature of human self-servitude to God, fasting, zakat, and all act according to Islamic teachings. It's because Alqur'an as guidance ask muslims to be calip (to be total). 


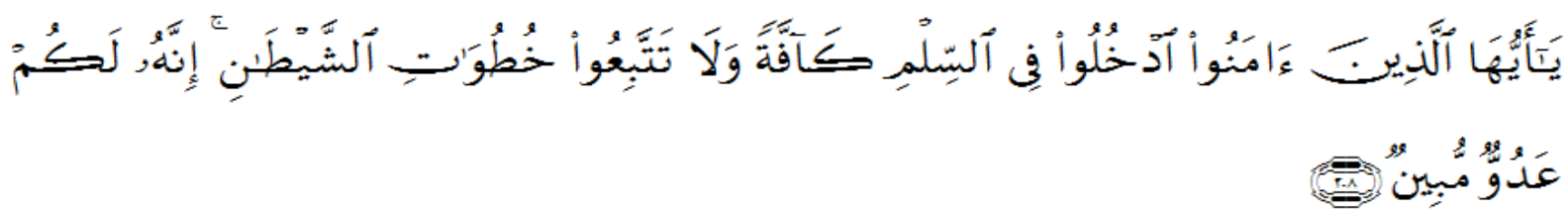

You who believe, come perfectly to Islam (by obeying all the rules and regulation of the Islamic religion) and follow not the footstep of devil. Verily, he is to you a plain enemy.

( Q.S.Al Baqarah: 208)

\section{Theoretical Basis}

\subsection{Prayer as Source of Spiritual Motivation}

The correlation of Prayer employee performance, and the companies, can ' $t$ be read linear, but it should be approached by phenomenon way. After it, we'll see the indicators as a form of a consequence from employee understanding toward Prayer and action in working area. That perspective can be started from seeing the spiritual motivation which would affect the process of its production. Without seeing this point, we will get the difficulty on behavior, orientation, belief and the soul dynamics from the employees with their intensity in doing Prayer as their duty and their responsibility.

In this part of the research which conducted at Batam shows that Prayer has given spiritual motivation toward its Muslim. That Motivation furthermore, forming a way of thinking, orientating and acting in its role as one of production factor in company. Prayer also as source of motivation can be looked at the employee living as a whole.

The daily routine in doing Prayer with truly belief will build a religious behave, it leads people to have perception on sense of working, production, achievement, finding good prosperity, willing to be royal to other people and etc. that's all as the reflection of spiritual motivation.

Motivation defined as the state of internal power, desire, dynamics and suggest people move toward a goal ( Mursi, on the objective 1997:91 ). While spiritual motivation is the main impulse which able to drive someone to perform and act creatively purposing one important part on their life to get the precious from God. Therefore, someone who has spiritual motivation will try hard to manage their life more actively and be the one.

The writer use "The protestant Ethic and the Spirit of Capitalism" theory to ease the way of seeing between the relationship on motivation and performance. According to Weber, the protestant assume life full of uncertainty, and no one knows human which the god will choose. According to Protestant lesson, "human life has been determined by destiny from the god and fate safety ( salvator ) will only be given to those who elected. But, human don' t understand about their destiny"(rahardjo 1989:41).

This uncertainty is so powerful to support the protestant in preparing live in a world as well as possible for them to be elected. Therefore, the Protestant working hard to full fill and gain much wealthy. A pattern of simple life and give great attention to the activities of production is protestants habit. Its lead to the understanding to the world view. Those views give big influence to American capitalism. It can be seen from the number of entrepreneurs in America was from protestants.

Meanwhile, in Islam, the revelation pertaining about whom Allah will choose is clear. For the uncertainty happen because it hasn't real appear. To be the one who able to be elected, someone must be religious. God. has given the guidance and two potential to people and piety. God grants freedom to use reason and piety or the potential. Each has consequences. For the muslims, consequences is characterized, as about a doomsday, heaven or hell.

Muslims also get information that its existence on earth occupying a position as caliph. The road survived to servitude self and bring treatise on earth called Islam. Prayer as pillar of Muslim is the affirmation from the consequences above. Thus, Prayer is the proof for the real Muslim.

Going further from that dimension on Prayer, can be drawn as the frequent activities. Prayer will give positive impact but it's too weak to gain the motivation of spiritual. In other words, Prayer $t$ is only the routine activities and no meaning inside that give positive idea to self and environment. The example is Allah has warned to Muslim that Prayer will be un useful, even misfortune, if all Muslims don't have good deed because of stingy and passive to the society. Then, woe to those who perform Prayer. For that is the one who drives away the orphan and does not encourage the feeding of the poor. More than that, people who neglect to do Prayer and no matter to the situation in that kind of environment referred to as liars of religions. So God warning in letter Al-Ma'un about that liars.

A muslim who understand the meaning of Prayer will not allow himself to be care lees, ostentatious, takes an orphans 
right, while perform Prayer five times a day frequently. Someone who perform Prayer and read surah al Ma'un won ' $\mathrm{t}$ let her life poor.it can be called as a source of economic motivation besides as requirement of his life, and as one of choice from God. isn' t the prophet Muhammad saw also reminded that poverty is closer to kufr ? Amuslim have to life prosperously (full fill well physically and soul) to bring into good ethic. Its worrying when somebody doesn't have God wealthy, they will breaking the rule, even law.

Therefore, the religious Muslim will make every effort to his life, or fulfill of the needs, the primary and secondary properly. An accurate point to ensure the welfare is when they go into the production process. Therefore, they will work hard and took their role in the process of production to ensure the continuity of their life. This impulse called as "capitalism spirit" in Muslim.

Placed the same context like in "ethics of Islamic" above, an employee who diligently perform Prayer will try to become good workman because there was an impulse within to win well-being. Therefore, the fulfilment of various needs on their life must be carried out in good according to the size of each individual and standards of the public welfare.

An employee who has spiritual motivation in running the duties and responsibilities will try to work properly if its Compared to each person, there is the difference between employees who have high motivation and who had no encouragement toward the motivation. On the first statement it shows the good performance because they had direction and clear targets. Moreover, there is more broadly orientation of their life. It is because the people are religious in all of aspect of life include in routine activities and working time. We can say it's as religious Performance. Those employees will build an exact understanding toward the function of Prayer in life, including when they had up his role as a workman or one important factor in his life.

Due to the understanding of the whole obligation to perform Prayer, all religious employee always will try to act according to the job descriptions. They are not accustomed, for example, work half-measures or neglecting to their duties and responsibilities in the company or wasting time at work. Even worse than its condition, like doing corruption. They are also able to reflect the spiritual transformation through Prayer in the form of a work ethos or various muamalah activities; that work is also a form of worship and the same glorious mahdhah; that working in a professional manner is also in order to seek the blessing from God. and so on. Professionalism is what lets employees to perform, even create a new things well. The excitement worked professionally will ultimately be seen in the company performance thoroughly. It is because the main actor that influences the performance of the company is human resources in it.

How adorable witnessed looks the religious worker in running day-to-day activities, not only where they in company environment, but also when they are in residence when associate with society. Because, work performance is not formal way to associate, a performance just shown during they stay in the company or in a certain situation, but it is being one part (personality) of oneself. It means that the religious employee performance is something that can be created through various way which is integrated into organization mechanism and working system in company that create culture support for the growing of an oreder religious, spiritual motivation is not an instant problem. Spiritual Motivation is the personal experiences. it is being community phenomenon, or broader than that, because the kohesivitas factor or a kind of culture, social environment in which individuals feels at home and to be free in expressing various of act.

In other words, spiritual motivation could only be built through a process of understanding and indi vidual consciousness toward certain religious values, as a place of implementing and instituting the values intensively and need certain "culture" which make the mahdhah activities especially Prayer running together simultaneously.

Just for reinvigorating the discussion above, the relationship between spirituality and improving the performance, need to insist that inside of religious person there is healthy body .A religious employee is someone whose having healthy body spiritual and physically. In the souls of healthy would be easy to respond good information in the environment surrounding. They are in a situation where the potentiality can work well. They tend to want to use ability rather than follow the honest potential. They also tend to capable on developing a way of thinking and a positive attitude, as rational, sportive, obedient to the chief, willing to step up and performance, optimistic, a progressive upholds the values of togetherness and honesty and fairness. Precisely, there are lot of goodness and positive point in a personal or employees who life organized because the good potentiality appear to them. Therefore, they will tend to be discipline, responsible, like to be virtuous to their fellow (solidarity social, piety ssocial), upholds efficiency and effectiveness of labor, doesn't like to waste the time. The point is that the employee who understand and involve the meaning of Prayer will have a good behavior.

An employee who perform Prayer 5 times a day will try to work properly according to measurements that has been set by the company. They loyalty oriented to the head of company, also dedicated to the system that enforced the company management. Not destructive, they easily understand such instructions or policy organization to an enterprise and 
skillful in implementing the program and activities. Therefore, they realize that meet the obligations as an employee was activity that is necessarily to get their rights as a worker. this conformity will be understood as a form of worship.

Meanwhile, both employees and company represent a group of people who needs wealthy. They also need a certain tips as the main reason why they are now in the same place, called for working to gain wealthy. Even, the businessman use tips to collect the factors of production like providing an employee. It's aimed to build a business activity. At the individual scale, business capitalization is also in the context of earning life.

In this perspective, the rewards received is in the form of wages or salary ( listed in a contract agreement work and rules remuneration) and various forms of allowance is the achievement in accordance with the causes that built on spiritual motivation that aims to get well life. Industrial relationship between workers and companies in this context can be understood in an equitable manner without any impression. Its for making the employees working properly and get high achievement, and the management give the reward as suitable with life standard.

For muslims employee by their spirit, the feedback is not only humane, or constituting the consequences and rights in relation to industrial relations with the company, but also in order to meet an exclamation of their god, Allah don't forget the need for this, as Allah said:

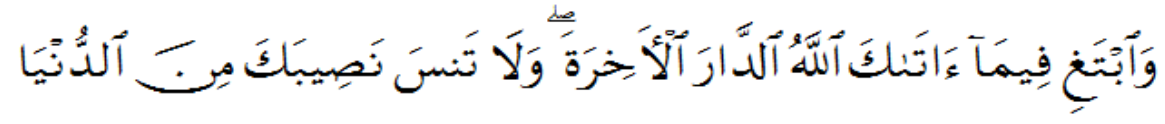

"seek, with that wealth which Allah has bestowed on you, the home of hereafter, and forget not your portion of lawful enjoyment in this world" ( Q.S Al-Qashash: 77 ).

The prophet Muhammad Saw. also reminded that the success of living in the world is a reflection hereafter; because the world is the field of after life. The prophet stated that al word al the afterlife ( the world is a mirror of the afterlife ) or $A l$ the world is the fields of the afterlife. This is where the spiritual motivation of muslims should be built to exceed the thesis weber above.

Al the Qur'an clearly rejected the views on human subservience to the god in the form of suffering, more suffer more religious. Islam has different point of view for this case, called as zuhud, the views of simple life. Unlike in the teachings of certain religious which sees suffering as a form of devotion to the god, Islam ask the Muslim to be active to full fill the needed.

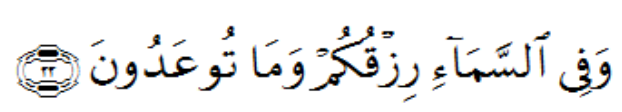

"And in the heaven is your provision and that which you are promised."(Q.S. Al Dzariyyat: 22)

Muslims believe to the presence of theology basis about wealth sources on the earth. Allah even draw promises to the life of human beings gather with his promises to the animal life for continuity in daily life .

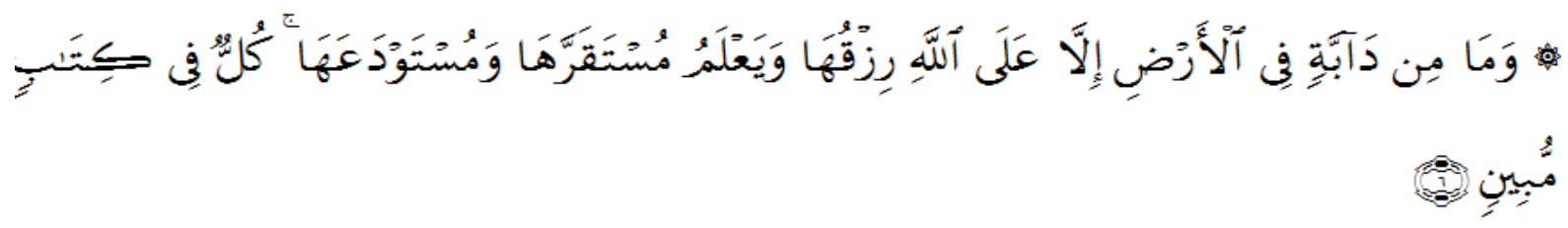

No living creature is there on earth but its provision is due from God. And he knows its dwelling place and its deposit (in the uterus and grave). All is clear in book of Lauh Mahfuzh. (QS. Al Huud: 6)

In other part, God also inform:

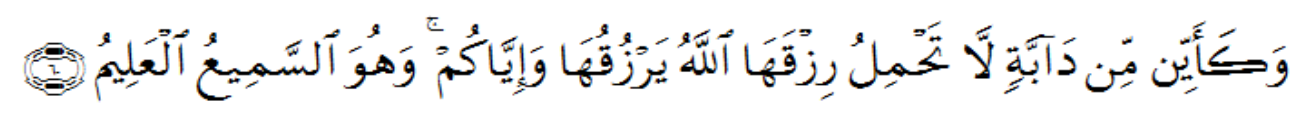

and so many moving creatures carries not its own pro vision, God provide for it and for you. and he is the all hearer, the all knower. (QS. Al Ankabut: 60).

Allah is fair neither to animals nor human. Believes to the letter above, a religious employee found its context in company. They felt that they have been on the right path in the effort to found life. The sense of believe that need for primary and 
secondary will be met because they receive a salary is relatively be sufficient to meet daily needs, and the belief that what they do is also worth of worship, will give quietness so they will work .

In other side, the company will get the beneficial point from the attitude and understanding from the employees, because of their reliable employees and productivity, targets the production are achieved, even it takes an over management planning. the other implication can be predicted as raise as the profit. This means that the company performance is generally good. Employees perform as well because having spiritual motivation that will be the most important factor for the company to be able to produce competitive products. Only a competitive products that will win the competitiveness. The demand for goods or the product of the company will increase. The accumulation can be seen from the revenue in company.

Therefore, the company will see employee who could be decisive for the success of production that is competitive as a factor that were producing lots and fortunately for the company. In other words, in terms of business, if counted the value of productivity employees to exceed the amount of salary they underwrite thing is expected. The company won't have the employee with that condition. Therefore, management companies will be adequate, give in return even rewards for certain work performance. The rewards of the company would improve the welfare of employees, while corporate cash flow will not be affected or minus because doing so, because added the value of competitive products is bigger than in which that element expense entailed to pay salaries, a bonus, and a various shapes rewards issued cash.

The relation between workers and recipocrality companies will encourage employees to work better and productive .If that occur is not limited to only at the level of individuals but collectively or most employees, or more they said has become ethos work employees thoroughly and live as a corporate culture, then the company performance was increase up in terms of quality and quantity. More than simply maintain this tradition, companies interested in making efforts would be even the internalization of the culture this as part of the identity of corporate (corporate culture). The company is interested to institute the ethos work of religious employee as coordination. It's possible to the employees will be alternates. But, culture companies should always live along with the dynamics of the activity of production.

Along with that, through a process of nature, it will grow among employees attitude to compete when you invent and students. Employee who perform religious has sportivity and love to compete. that's not matter if the employees want a bonus or reward the company through a good performance, even with high achievement. In this context, vying in good ( work ) will look in the performance of employees. At this level the performance of the company is atomically will be raised as well. Of course differ with competitions by the profane. The competitions among employee who life with good spiritual will stay in the limits of propriety toward the rules existence. They can discriminate between competition that of Islamic merely compete. On the last called it ' $\mathrm{s}$ like competing by every way, as slander, mutual scuttle or forming cliques that tends to an employee or a group of workers at the expense of others. Meanwhile for employee who is religious competition will be based on a feeling of affection against fellow without neglecting the side of quality.

The point is where the company and the employees having a similar reasons to advance the spirit motivation to find its optimal effectiveness to reflect the spirit of capitalism. Capitalism as one of paradigm having its own orientation for Islam and will not be discussed broadly here. Islam goes to the values of progresivitas on production and economic activities. But, Islam refuse the exploitation in economic, like to the neighborhood, having goods storage production to the certain purpose that tends to make other damage, monopolistic, and further something legal in Capitalism.

Back to the main theme that spiritual phenomena with motivation and the interests of companies even companies whose handled by people also have an orientation that more or less equal with motivation spiritual above. Here the writer will be observed in industrial areas Batam. The company employees there, in the last few years, exhibiting the phenomena of being more religious. Besides influenced by the external factor or macro variety of life in the Indonesia in the past two decades which in a particular perspective is also said the excitement of new the spirit, the spirit of employee religiousness also grow because the company management support the establishment of a religious order. for example, Batam company provide infrastructures and facilities for their employees in doing. Prayer In this context Batam Company provide two mosque.

The religious ethos from employee is getting better; it can be seen among others, the activity in running the obligation for Prayer five times a day at a certain time, the other good deeds like spiritual activity in the neighborhood of the company. That practices give good relationship among the employee, both vertical and horizontal, employees discipline, and so on. it's hardly ever to hear the conflict among employees and tension in connection industrial relations between workers on one side and with other company management. The harmonious mean something attractive to create conducive working, being creative, even innovative.

Is there any other thing for the workers to indicate the best performance beside the peaceful climate and low pressure inside? It can be concluded that the performances of employees in Batam Company is straight comparative to achievement of the company performance (the details will be shown at the end). This research is interesting because it can 
reveal some recent fact that is different from the research before. This is not strange because basically research is done within the span a given time. The situation as well as the complexity of a problem or variable which accounted for in every of that period also different.

If on some research in the same place first mention that formerly revealed that in general money a factor whose main motivation for employees in working, on the other side work more focus to the efforts pursuing the progress of themselves. Now, the findings are as turned. There is an indication that the employees spirit working in Batam company impelled spiritual motivation, and it was born, strong among them due compliance in enforcing Prayer five consistently, based on the understanding of the true, Prayer sincere which done by soul.

The religious performance is the reflections or influence of spiritual motivation growing along with the dynamics of the company activities.it is the evidence that the spiritual motivation can be re viewed through some tendency which can be observed outwardly. This Is the observed variable, namely the involvement of ritual, the involvement of dogmatic, the involvement of knowledge, the involvement of experience and the involvement of the consequences ( glock and stark, 1968: 11 ).

"The religious performance is measured based on performance indicators of philosophical religious, and performance a spiritualist. The performance of philosophical measured based on the utilization of natural resources, technological expertise and capital in Islamic. The performance of spiritual measured based on the level of surrender, honesty, trust, intention altruistic in work as well as Islamic orientation. One reason that Prayer as an indicator with prayer and fasting because adapted to the ability of humans consisting of physiology, psychology and spirit, where these things that can increase work performance" (Partadiredja, 1994:98;Zadjuli, 1999:10).

Spiritual motivation even can be seen on indicators of professionalism from employee in working. The religious employee performances seen from the sense of responsibility and discipline in work, and ultimately was a factor in the production process being painstaking, efficient and effective. At the point of this is an employee in a state of fitness to work. Any company always hope that the condition of an employee always good because give positive view for the company performance in general. Answering the questions at the beginning, how can Prayer support the spiritual motivation toward the working activity for personal and company performance better?

\subsection{Prayers: from Asceticism to the Spiritual}

For some people, the idea of connectivity Prayer between and the performance of an employee at a company may be considered as grid from a fire, even further it might be considered as impossible theory. Among this tends to look Prayer as its ritual rather than spiritual and ritual as well as in one whole .this view inclined the value of Prayer and placed Prayer as only responsibility, even as burden for Muslim. If Prayer has actually done, then the obligation for a muslim has been completed, so the general conscious is often seen. It is unsurprising if Prayer is only perceived as a routine activity that rhythmic; start from ablution which it is prefixed and physical activity of veil until last salute followed by praying and is hurling that rewarding until there alone .In other words, this view prayer is seen as a region religious individuals, the activity temporarily production in a company constitutes the profane, and the two things that don ' $t$ have any correlation. "limit the flow of spiritualize religion of Islam only to the ritualistic and it ' $\mathrm{s}$ so gradually neglected its implementation (Prayer is more rarely, praying when having trouble, fasting if not sick and etc)". ( Amsyari: 1995: 171).

Its true that Prayer is the activity of ritual. However, as a ritual Prayer also contain elements of motion of the body that is not in vain. Various views has been served by many experts about the meaning of each movement from. Prayer Not only physically movement, but also a meaning in the psychical and harmony physic "... prayers contains activity that produces bio-energy who lead the culprit in the condition of being balance between soul and body" (Wibisono, and 1985 in Ancok, 1995, 1995: 98 ). Likewise nizami ancok ( in 1995 ) that, Prayer is full of physical activity and night prayer especially night prayer, it shall not be denied Prayer also increase employment. M.Sholeh ( 2000 ) say that there is an increase of change response to the body endurance imunologic.

In fact, Prayer movement itself has base philosophy in human relations (servant) and the god of the creator. Prayer is the symbol constituting Symbolization of recognition of greatness and his dominion, as a muslim is not deserve to be a boast. He shall perform totally to The God

Prayer in Islamic teachings sum up the interpretation above. Prayer constituting command of Good and shall be obliged to the law for muslims.in any condition; a muslim not allowed to leave the worship. However, as a ritual, Prayer is the activity of spiritual. So prayer is ritual as well as spiritual. In hail the implementation of Prayer there are a lot of things in the context of the relationship between humans ( a being ) and the creator, God. Affirmation is mentioned by someone in their Prayer by giving: iyyaa kaana budu waiyya kaanasta 'ien only to you we worship and only to you we appeal help ). Affirmation is also spoken a muslim when performance prayer perform when sit tahiyat, at the time when 
read two sentences syahadat that carries substance recognition that there is no except God and Muhammad is the messenger of Allah that serve as a role model of muslims.

As a ritual in religion Prayer in Islam, including part of the conviction. A form of ritual derived from the teachings of the Prophet Muhammad, as his words were: Shouluu roaitumuuni ushshalli kamaa (Prayer you all as you see I am doing a Prayer. And, hadiths about Prayer almost all is mutawattir. The validity of this treatise of Prayer never changes and questioned people up to the age of 14 centuries. That then there are a number of strange thoughts, or even distorted, like praying is done by means of whistling, could use the prayers of local-language, not Arabic, and others, it turns out that all had been unable to shake the existing of Prayer activities. Therefore, too careless if the people accepted ritual prayers the validity of this. In fact, God own convey treatise prayers to the prophet muhammad Saw through a process of being thus saw a dramatic, which is through isra and mi'raj who in his day, even to this day still having a level of complicated high. The story of isra and mi'raj increasingly assert how the perform Prayer is very important. The prophet muhammad saw calls as the main pillar of Islam, prayer as he never tell: Prayer is a pillar of religion. He who uphold Prayer he had established religion. Whosoever leave Prayer he has pulled down his religion.

Meanwhile, there are so many understanding among Muslim who look at the relationship of Prayer and a good employee performance upon a company in simplist is. The views of the latter it tends to trust correlation in enforcing the Prayer discipline and ethos of employees working in indiscriminate sensor or uncritical and not in the corridor of theological argument nor scientific adequate. They might say that all virtue and that of Islamic would certainly produce kindness. Not mistaken, indeed. However, it is hard to find a conclusion to be able to be a lesson together.

The research conducted in industrial areas of Batam about the influence of Prayer toward employees performance give essential information about the existence of scientific arguments. The aspect of spirituality employee who explored not only pertaining to prayers, but also understanding them about creed, the nature of prayer and devotions other like fasting. This chapter focused on aspect of Prayer as a source of spiritual motivation .

This research is intended specifically to examine the assumptions and hypotheses that spiritual motivation has strong relevance to the performance of someone better. In line with it, the research also could serve as a new understanding of the balance toward the thesis of Max Weber in The Protestant Ethic and the Spirit of Capitalisme, as mentioned above. On this famous thesis, published at the beginning of the 20th century, recalled that the Protestant ethic, Weber has given birth to the motivation of trying (capitalism) that significant rather than on other religious groups. The Weber thesis is considered as a new breakthrough in the field of Sociology of religion.

But, unfortunately, Weber reputation when discussing Islam as a religion that has no important elements required to grow certain spiritual as motivation owned the protestant, not as good as the thesis above. According to weber, monotheism in islam constructed years in mecca can ' $t$ give birth to asceticism as one of the important requirements to give rise to the spirit of capitalism. Weber, among others, call the history of islam is soldier history. In other words, Islam were not having value that is as strong as the protestants in provided inspiration for the growing of spiritual motivation who directs his people to always dauntless in trying to ( read: working )

Discussion at this part actually didn ' $t$ deliberately to Weber thesis. But there are matters which need to be analyzed to make it balance. Weber thesis about Islam reap considerable criticism, not only from among muslims, but also especially from western sociologist and logician who master the study of islam. One among critics for Weber was from Brian S. Turner the students of flinders university, south Australia. Beside talk about Weber incons istency, Turner also said that weber as one who does not have the mastery toward islam in an adequate manner. Turner, quote from Albert Hourani, tendensiusly wrote: christians strong, because they are not a true christian, while those muslimeen weak because they are not true muslim.

Outside of the debate, Weber give essential information about spiritual motivation in growing the economy mental. the real study also been done by Robert N.Bellah toward Tokugawa in japan in growing japanese capitalism that he value to compete the growth of American capitalism. Another study in japan mention budhisme zen is the attitude of religiousness and ethos of work in the land called as sun rises country. "working, for them, is not solely economic activity but good deeds in zen" ( Rahardjo 1989:39).

There are at least two things must be understood in this context. First, Islam, as like in Protestant ethic, contain progresivitas values as well as the specific motivation for working and trying to be good, even to be top achievers. When the Protestant worshippers, as Weber calls the spirit of life, has to be the chosen one of God, so that the House is trying hard to do as well as possible during the life of the world, then they foster a spirit that supports Islam -capitalism.

Second, islam is a source of religious motivation not only infinite-dimensional material but also spiritual equally. In this case, the prophet muhammad ever, if a man who seeks happiness for his world, and he just get worldly pleasure. Whoever who seeks happiness for life the afterlife he got blissfulness the world and the afterlife. 


\subsection{Prayer Animate Social Interaction in Companies}

As rahmatan lil'alamien, Islam is a religion that not only set the relationships between human beings and god (transcendence), a spiritual nature but also contain the source guidance for human life in the world. Alqur'an in various occasions describes as explanatory for directions and instructions as well as distinguishing (huda li al naas wa bayyinai min al huda wa al furqan). As a clue ( al huda), the descriptors (al bayan) and distinguishing ( al furqon ), the $A l$ Qur'an as a major source of islam is a perfect religion. God confirmed this when the Prophet Muhammad haj wada of the last year: in his the prophetical:

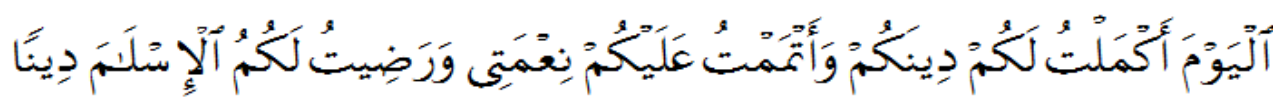

this day, I have perfected your religion for you, completed my favorit upon you and have chosen upon for you Islam as your religion.Q.S. Al Maidah:3)

Prayer as one of the mahdhah also the value requirements that not only dealt pertaining to spiritual but also a social dimension. In many Islamic context, Islam is social part, Not a social. It means that as much as the perform of mahdhah and personal space, implication and the moral message include others., in the context of Prayer it would appear to be the congregational prayers. Therefore, Prayer allow occurring social interaction among muslims.

\subsection{The Value behind Congregation in Prayer}

The system of worship in religions always has a dimension of spiritual and ritual. When the affair is more related to the belief, ritual procession depicting oral and physical activity: such as bending, reading prayers, and all religious attributes. As the experience of religions, two things, spiritual and ritual, is formed in addition to the his torical and anthropological guide Revelation (for Samawi religions).

So do in Prayer On the side of its rituals, the worship of which as the muslims pillars has a very strong social dimension. Look at the practice by muslims in a mosque or mushola.In daily life, either in village, housing complex, offices, even in the shopping centers, the practice congregation in Prayer will show the joint activity, as been queuing up at the time of ablution, and then assemble form lines regular, lifting a priest, the rites and pray together. All the motion take place on a regular basis and led by a priest through the words: God), and terminated by regard with seeing the head to the right hand and to the left. After that, they do wirid-ziki that can be carried out jointly led by the priest or held in single. Phases on rites Congregation .

Pilgrims activity in industrial areas Batam for Congregation in Prayer also can be said as affirmation to live in peace and in social life harmonization. Another good point is this togetherness would not rule out the affairs of spiritual in each pilgrims in Prayer or followers.

All these days, Islam does not know the system of penance a provident in which there is a kind of guarantee of safety hereafter for its adherents from a leader who is regarded as the representative of the lord. The priest for congregation in Prayer indeed a role as a leader. However, the leader of pilgrims will not guarantee the congregation in perform Prayer would be acceptable or not. Prayer is personally becomes the responsibility of each individual. Congregation in Prayer, thus, can be a 'paradigm' social interaction that remains promote individual responsibility on one side, and direct involvement of physical and emotions with other part.

When Congregation in Prayer at the traditional community of Muslims that occupy a certain area, like village, Hamlet or a Neighborhood could run well, a similar practice can be implemented in a community that is functional as in a company. Many companies that provide facilities as a mosque or musholla for perform Prayer More than just a venue to, Prayer musollah, mosque or community at a company in fact formed an organization of Muslim spiritually.

This practice occurred at Batamindo Batam. Unless there is a temple and a church in Batamindo Industrial Batam, there are two mosque around the environment manufacturing. The practice of congregation in Prayer was held on two units mosque. As the infrastructure that stands to be part of the overall facilities in the neighborhood of the mos que, that place is certainly as a message from industry managers to employees who should carry out the obligations of muslim by visiting and worshiping in it. Unless it is a tradition that has lasted many years, two buildings were also able to provide its own spiritual motivation to work hard that an employee does not need to leave important things such as Prayer.

The intensity of congregation in Prayer at Batam run annually. The management realize the importance of employees religious performance is attempt to improve the performance of the company.

The flurry of employees in running the tasks from the company didn't reduce their passion for Prayer and it was done with Congregation. Indeed, it is not likely it was done at a time. It is given the number of employees who are so numerous and 
schedule in each part are not the same. But, at least there is the main time according to organise prayer times to Congregation in. Prayer In addition, the habit of Congregation in Prayer has become muslims employee awareness to continually carry out this obligation than perform Prayer by alone.

Of course there are still many things that can be excavated from the moral messages contained at the congregation in Prayer Islam does indeed give priority to the traditions of community, regularity, and harmony in human relations. Customs employees Batam for years as the various attitude spawned up to a certain extent either as workers or as Muslims.

\subsection{Social Solidarity}

No doubt, the habit of congregation will infuse a solidarity soul. Why not. When the employees met in a mosque or mushola in Batamindo, they always do social interaction. A lot of stories and discourse put forward at the time, running toward the place of worship to take off the boots , and the journey back to work after of the mosque.in this is religious situation and full fill the same purpose, easy for them to give empathy for various problems that raised. And, indeed, muslims understand that fellow muslims were brothers. the warning in a surah al ma'un above, and various advice from the Prophet Muhammad in a variety of senses which in essentially knocking the sense of regard as the basis of togetherness and social solidarity among the employee.

This social cohesivity exceeding the processes of communication, yes for the behavior in had been on the standard for social interaction that involves the emotions that in certain standard as the religious emotion. This is the affection side being a muslims for employees. Islamic understand not only on the side of cognition involvement but also psychologically. Aconducive situation to communicate is social capital which is not in meaning as employment relation only, good for them which one level or vertically between superiors and subordinates. The spiritual Motivation is more trained in these kinds of situations. An urge to work or actualization himself which based on the values of religiousness that will be carried away by itself.

\subsection{Personal Progressive}

An employee who is diligent perform Prayer as the other muslims, in general easily have led to a kind of links and in terms of those values are written in Alqur'an and al hadist. One of the Islamic value is progressiveness. One who executes Prayer accompanied by seriousness, focus , routine, altruistic, always easy to repair self, and Prayer as a ritual symbolize message describing Progressiveness Substance about it. That the person is always reminded by the time when travel because there is a good deeds from day to day. The prophet saw said: "today must be better than yesterday. Whoever his practice on the day was the same as yesterday then he will suffer. If practice in the day of this is worse than yesterday, then he is reprehensible."

This is the ethos of the Prophet greeting a muslim in his work. The work must always reflect progressiveness. It demanded the power of creativity and innovation of employees live with the duties and responsibilities in the company.

\subsection{Prayer Salubrious the Soul and Body}

Prayer, containing physical movement and spiritual activity, large benefits in the form of a balanced for human being. And, the reality is indeed like that. How much does not. At a time when people in General still soundly sleeping, a muslim has to wake up to perform Prayer In fact, for some people, they had built to enforce the night Prayer Physical health was ablaze from the routine activity of that sort. The morning is a time in which nature provides such abundant oxygen, a very good thing for the health of the body. At the same time, the prayer is gestures that moves a number of points, is the smooth flow of blood. There are two pull at once in the middle of the body that performs Prayer Not only make healthy but also to physical needs.

On performing, Prayer basically done when the body break away from the activities that are merely material. it tried to enter the Middle realm of transcendent through the machination part. However it is not easy to do, because after all God is the great holy to be closed with human soul. But, at least the intensity of Prayer will bring a person to a particular spiritual in his transcendent approach. Put Prayer as an exercise (tazkiyah nafs). If machination could reach a certain level, it is not only for physical healthy and logical reasoning (intellectual), but also emotionally (Emotional-Spiritual-Quality or ESQ).

Employees with potential ESQ like this will obviously be a dynamic worker, careful, efficient and effective. Many of the ideals that could was conceived and attempted through the work. Whoever is interested to have his religious life of graceful employees like this? Worship prayer, thus, making someone have balancing in body and soul as well as emotional.

Just imagine from $85 \%$ of the employees in Batam is muslim. When only half of that number praying with orderly and persons practitioners rigid austerities, so its influence on employees work achievement that will be very productive. 
Increase in employee achievements will have an impact on productivity of industrial and certainly have an impact on improving the well-being of the employees themselves.

\subsection{Achievement as the Blessing of Prayer}

Based on the description, its convincing enough that the employee's accomplishments in Batamindo company influenced the growing spiritual motivation of the prayer in perform Prayer This testing that done to the employees assured the conclusion above is mainly the blessing of. Prayer The prayer becomes an important variable of the growing spiritual motivation, and the spiritual motivation which allows its employees to perform the transformation of the spiritual values into the work ethic and professional performance.

\subsection{Congregation in Prayer Affect the Economic Activity}

Until this stage, the understanding of the spiritual motivation which results in the performance of a religious employee who was born from the prayer has already applicative. Prayer in addition to the ritual activities remains a purely functional, as thrust employees in work, create and achieve economic objectives.

Prayer is having the power for muslims in the domain of production or economic activities. Have a positive impact if this third pillars of islam was held in congregation. This is the most real motivation as form of employee spiritual that being the blessing from Prayer activities in the context of production activity in the company. Some effort extracting information on correlation will be done through various approach.

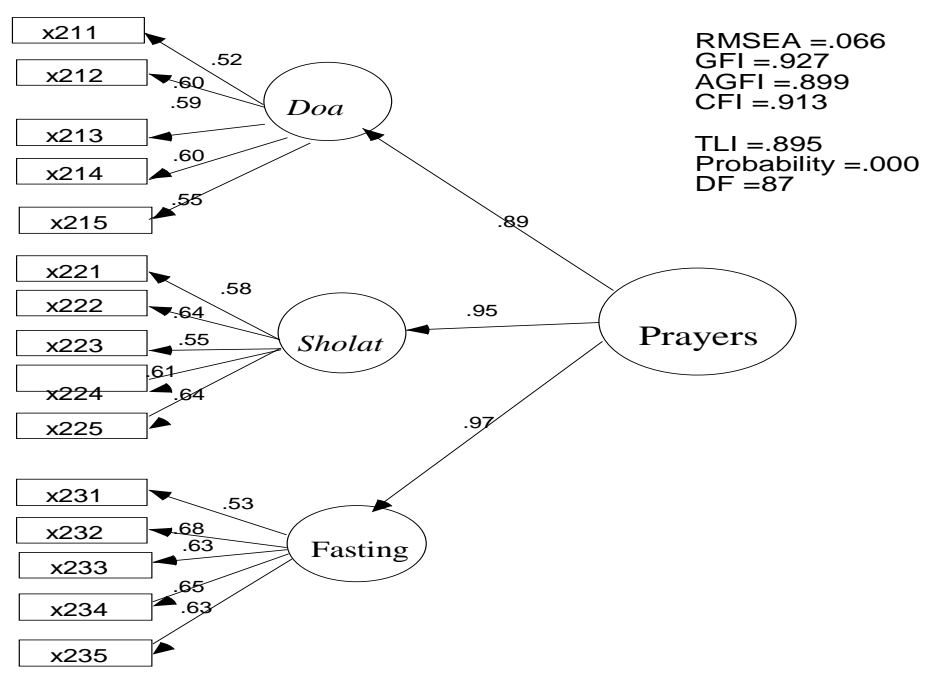

Figure1. With Second Order Confirmatory Factor Analysis

\section{The Result of Research Dissertation}

Variable proposed as an indicator of Prayer in observations level of praying and fasting. The test results with second order confirmatory factor analysis appears in Figure 1. To find out if the measurement model has compatibility with data, presented the following e valuation of the Goodness of Fit Indices (table 1). Results of the evaluation of models turned out to be from around the criteria used shows a less good results, it means that the model does not fit the data. The test results with second order confirmatory factor analysis appears in Figure 1. To find out if the measurement model has compatibility with data, presented the following evaluation of the Goodness of Fit Indices (table 1). Results of the evaluation of models turned out to be from around the criteria used shows a less good results, it means that the model does not fit the data.

Table 1. Evaluation criteria for Goodness of Fit Indices

\begin{tabular}{lccc}
\hline Criteria & Results & Critical Value $*)$ & Evaluation Model \\
\hline Chi-Square & 286.64 & Relatively Small & Less Good \\
Probability & 0.00 & $\geq 0,05$ & Less Good \\
RMSEA & 0.066 & $\leq 0,08$ & Good \\
GFI & 0.927 & $\geq 0,90$ & Good \\
TLI & 0.895 & $\geq 0,95$ & Less Good \\
\hline
\end{tabular}

Source: *) Hair (1992), Arbuckle (1997), Muller (1996) 
Thus the model need to be modified. With modification based on indices, modified the test results appear in Figure 2.

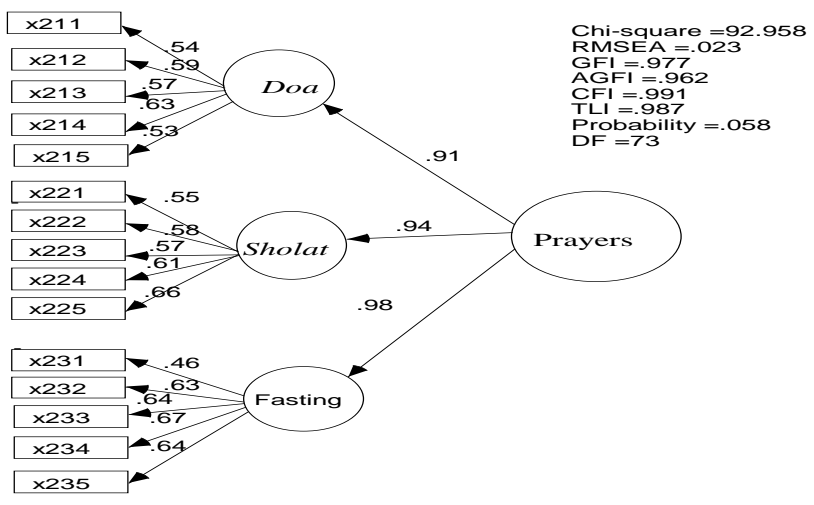

Figure 2. Measurement of Modified Worship with Second Order Confirmatory Factor Analysis

To find out if the measurement model has compatibility with data, presented the following e valuation of the Goodness of Fit Indices (table 2).

\begin{tabular}{lccc}
\hline Criteria & Results & Critical Value *) & Evaluation Model \\
\hline Chi-Square & 92.958 & Relatively Small & Good \\
Probability & 0.058 & $\geq 0,05$ & Good \\
RMSEA & 0.023 & $\leq 0,08$ & Good \\
GFI & 0.977 & $\geq 0,90$ & Good \\
TLI & 0.987 & $\geq 0,95$ & Good \\
CFI & 0.991 & $\geq 0,95$ & Good \\
\hline
\end{tabular}

Source: *) Hair (1992), Arbuckle (1997), Muller (1996)

Goodness of Fit table along with its critical value can be raised from a variety of criteria proposed model has compatibility with the data. Next to know the variables that can be used as an indicator of worship can be observed from the loading factor value or coefficient of lambda on table 3

Table 3. Loading factor measurement of worship

\begin{tabular}{|c|c|c|c|c|}
\hline variable indicator & Loading factor $(\lambda)$ & $\begin{array}{c}\text { the } \\
\text { Calculation }\end{array}$ & $\begin{array}{c}\text { Probability } \\
\text { (p) }\end{array}$ & Description \\
\hline TPDoa & 0.91 & & & significant \\
\hline Shalat & 0.94 & 8.0823 & 0.000 & significant \\
\hline Puasa & 0.98 & 7.7094 & 0.000 & significant \\
\hline
\end{tabular}

The table shows that indicators level, implementing prayer significant, prayer (shalat) and fasting seen from the value of as much as $0.000 \mathrm{p}$. (Source:Wibisono, 2002)

\section{References}

Amsyari, F. (1995). Social Challenges The Islamic Kaaffah And Its Application In Indonesia, Jakarta: Gema Insani Press.

Arbuckle, J. L. (1999). Amos 4 User Guide. Chicago: Smallwaters Corporation.

Djamaludin, A. (1994). Islamic Psychology, Yogyakarta: Library Students.

Glock, C. Y., \& Stark, R. (1968). Christian Beliefs And Anti-Semitism, New York: Harper \& Row.

Hair, F. H., Tathan, E. A., Anderson, R. L., \& Black, W. C. (1992). Multivariate Data Analysis. New York: Macmillan Publishing Company.

Meller, R. O. (1996). Basic Principles of Structural Equation Modelling. An Introduction to Lisrel and EQS. New York: Springer. https://doi.org/10.1007/978-1-4612-3974-1

Mursi, A. H. (1997). Human Resources Productive, Jakarta: Gema Insani Press.

Rahardjo, M. D. (1989). Zen Buddhism's Work Ethic and Japan. The Journal Science And Culture Ulumul Qur'an, 1(1).

Rais, M. A. (1998). Social Unity Formula Stormed Gaps, Bandung: Mizan.

Sholeh, M. (2000). Influence Of The Change To Increased Tahajud Prayer Response Body Endurance Imunologik, Dissertation: University Of Airlangga. Surabaya.

Tasmara, T. (1995). Personal Work Ethic, Jakarta: Muslim Bhakti Endowments Funds. 
The Ministry Of Religious Affairs. (1990). Al Qur'an And Its Translation, Jakarta: Bumi Restu

Wibisono, (2002). Spiritual Motivation, Influence On Performance Of Employees In The Manufacturing Industry Sector Sub Batamindo, Batam, Dissertation: University Of Airlangga, Surabaya.

Zadjuli, S. I. (1999). The Human Form Becomes The Caliph At The Earth Makdaniyah, Surabaya, Indonesia: Center For Policy Alternatives.

\section{Copyrights}

Copyright for this article is retained by the author(s), with first publication rights granted to the journal.

This is an open-access article distributed under the terms and conditions of the Creative Commons Attribution license which permits unrestricted use, distribution, and reproduction in any medium, provided the original work is properly cited. 